\title{
A Study on Chinese-English Translation of Intangible Cultural Heritage from the Perspective of Eco- Translatology
}

\author{
Li Hong \\ School of Foreign Languages, Quanzhou Normal University \\ Quanzhou, Fujian, China \\ hongli8065@163.com
}

\begin{abstract}
Intangible cultural heritage (ICH) in China is the epitome of the culture and spiritual value of the Chinese nation, so ICH translation for international publicity is significant for China to introduce its culture to the world. To ensure the effective intercultural communication and maintain the national cultural characteristics, in the framework of Eco-Translatology, the translator is supposed to strike a balance of the (linguistic, cultural and communicative) ecology between source text and target text by optimizing translation methods when translating ICH introductory texts from Chinese to English so that people around the world can appreciate the charm of Chinese traditional culture.
\end{abstract}

Keywords-Intangible cultural heritage; Eco-Translatology; Textual ecology; Balance

\section{INTRODUCTION}

The "intangible cultural heritage (ICH)" means the practices, representations, expressions, knowledge, skills - as well as the instruments, objects, artefacts and cultural spaces associated therewith - that communities, groups and, in some cases, individuals recognize as part of their cultural heritage. (UNESCO) [1] It is the reflection of the diversity of cultures and the creativity of humankind.

For its long history and splendid culture, China has currently become the country with the largest number of world-class ICH items. As a living cultural form, ICH in China embodies the inheritance and continuation of traditional skills and national spirit and is a fundamental component of Chinese culture. In recent years, with China's rapid economic development and its greater influence on a global scale, Chinese civilization has attracted worldwide attention again. Under the circumstances, it is necessary to promote Chinese culture to go out to enhance intercultural communication with other countries. So ICH translation for international publicity may be a feasible way to introduce Chinese culture to the world.

\section{ChinESE-ENGLISH TRANSLATION OF INTANGIBLE CUltural Heritage IN CHINA}

Translation of ICH introductory texts is part of translation for international publicity. Despite the rich cultural resources in China, ICH translation from Chinese to English is still not satisfactory both in terms of both quantity and quality.

So far there are some bilingual materials published and issued in China including two books about China's worldclass ICH and some directories of ICH in the provinces such as Fujian, Shanghai, Sichuan. In addition, other bilingual translations can be found scattered in travel guidebooks of some provinces or cities. For the internet sources, there are very few English introductory texts on the official websites of $\mathrm{ICH}$, whether at the provincial level or the national level. Just a few ICH translations appear on the provincial and municipal tourism websites or culture websites.

As to the translation quality of ICH in China, previous researches refer to various problems involving some mistranslation incurred by translators' irresponsibility or carelessness such as spelling mistakes, grammatical errors as well as the irrational application of translation methods like transliteration, transediting and so forth. Poor quality in translation will hinder the spread of Chinese culture and weaken its international influence, so it is imperative to improve translation quality of ICH in China at present. To address the problems, scholars has put forward some suggestions from the different perspective such as frame theory, adaptation theory, cultural diversity etc. (Lu, 2017; Tian, 2012; Chen, 2013) [2-4] Various opinion in previous researches is the reflection of scholars' attitude towards cultural differences. Compared to other translation for international publicity, ICH translation aims to serve the target language readers as well as preserve the cultural heterogeneity. According to previous researches, no consensus has been reached on the selection of translation strategies or methods. It is thus clear that translating ICH in China is a task tricky to complete but worth exploring further. Hence this paper is to take Eco-Translatology as its theoretical framework to probe into feasible strategies of translating ICH in China from Chinese to English to ensure the effective intercultural 
communication and maintain the national cultural characteristics as far as possible.

\section{THEORETICAL FRAMEWORK: ECO-TRANSLATOLOGY}

Translation studies constitutes a discipline in its own right with the interdisciplinary characteristics. In the early years of this century, inspired by the Darwinian principle of adaptation and selection, Eco-Translatology was initiated by Professor $\mathrm{Hu}$ Gengshen. It is an attempt in the field of translation studies by integrating ecological concepts into translation research. It bridges natural science and humanities and social science.

Eco-Translatology is an emerging eco-translation paradigm of Translation Studies from ecological perspectives. With metaphorical analogies between the translational ecosystem and the Natural ecosystem, and conceptual borrowings as its methodology, Eco-Translatology probes into translational eco-environments, textual ecologies, and "translation community" ecologies, as well as their interrelationships and interplays. Regarding the scene of translation as a holistic ecosystem, it describes and interprets translation activities in terms of ecological principles of ecoholism, oriental eco-wisdom, and Translation as Adaptation and Selection. (Hu, 2013, p.485) [5]

The application of translation strategies tends to be relevant to the understanding of the essence of translation. For instance, scholars of linguistic school take equivalence between the source text and the target text as its principal object of study; Functionalist approaches see translation as an act of communication and a form of action involving not only linguistic but also social and cultural factors. (Palumbo, 2016, p.59) [6] That is to say, when choosing translation methods, the former mainly focuses on the analysis of language meaning and form and the latter stresses the communicative function of a text. However, Eco-Translatology shows quite different cognition of the essence of translation. Within its paradigm, "Translation as Eco-balance" is taken as one of its core concepts. Eco-Translatology is really a sort of translation philosophy; translation strategies or techniques are actually the balancing act of translation ( $\mathrm{Hu}, 2013, \mathrm{p} .198)$ [5].

Textual ecology is one of the objects of Eco-Translatology. According to Professor Hu (2013, p.91), textual ecology refers to the textual eco-environment and the living state; source-text ecology includes linguistic ecology, cultural ecology and communicative ecology in the system of source language; target-text ecology includes linguistic ecology, cultural ecology and communicative ecology in the system of target language. [5] The living state of a text is inevitably subject to the translational eco-environment in which it is. When translating a text from the source language to the target language, in view of the differences of the textual ecoenvironment, the translator need to adapt to and reconstruct the target eco-environment for the survival of the text. More specifically, the translator is supposed to strike a balance between source-text ecology and target-text ecology at the linguistic, cultural and communicative levels by optimizing translation methods to minimize the misinterpretation or loss of information in the course of textual transplant. Thus EcoTranslatology gives us a fresh perspective to interpret translation process and cope with translation problems. Then striking a balance between source-text ecology and target-text ecology may be implemented as a strategy in the ChineseEnglish translation of ICH in China.

\section{TRANSLATION OF INTANGIBLE CULTURAL HERITAGE IN CHINA UNDER THE GUIDANCE OF ECO-TRANSLATOLOGY THEORY}

Due to cultural diversity, ICH in China covers a wide range of categories involving many aspects of people's spiritual life like literature, music, dance, opera, craftsmanship, customs and so on. Accordingly the complexity of these items poses a big challenge for the translation of ICH in China. In consideration of these, in the framework of Eco-Translatology, the following sections are given to illustrate how to strike a balance of the (linguistic, cultural and communicative) ecology between source text and target text by selecting feasible translation methods to reconstruct the textual ecoenvironment of the target language in the practice of translating ICH texts from Chinese to English. Hereinafter ST and SL stand for source text and source language; TT and TL are short for target text and target language.

\section{A. Balance of linguistic ecology between ST and TT}

Chinese differs from English in various aspects because they are not in the same language family. As to the balance of linguistic ecology, it lays stress on the harmony between textual linguistic factors like lexicon, syntax, style, rhetoric, etc. Different mode of expression between these two languages should be first taken into consideration when translating a text from Chinese to English. If translating ST word by word, it is likely to produce TT with vague expression and confused logic and finally leads to misinterpretation or loss of SS information.

ST1：受地理环境、风俗习惯、地方文化艺术等因素的 影响, 蜀绣在长期不断的发展过程中逐渐形成了严谨细 淢、光亮平整、构图疏朗、浑厚圆润、色彩明快的独特风 格。（Shòu dìl ì huánjìng, fēngsú xí guàn, dì fāng wénhuà yì shù děng yīnsù de y Ǐ ngxi ă ng, Sh ǔ xiù zài chángqí bù duàn de fāzhă n guòchéng zhōng zhújiàn xíngchéngle yánj İ n xìn ì, guāngliàng píngzhěng, gòutú shūl ă ng, húnhòu yu ánrùn, sèc ă i míngkuài de dútè fēnggé.)

TT1: By the influence of geographical environment, customs, local arts, culture and other factors, it has gradually developed its unique style as follows: rigorous in technique, subtle in stitch, and exquisite in design, with exact light-dark contrast, proper layout of patterns, even distribution of thread, perfect effect of vision. (Tang et al., 2016, p.106-107) [7].

ST1 is neatly worded and reads catchy by using fourcharacter phrases to show the characteristics of Shu embroidery. Each phrase contains the same number of characters and relates to different aspects of the Shu embroidery craftsmanship. However, through comparative analysis, it is found that there are differences in the construction of the italic phrases: 构图疏朗 and 色彩明快 are 
the subject-predicate phrases while 严谨细淢, 光亮平整 and 浑厚圆润 are just modifiers with two adjectives put together. This requires the translator to look for the intrinsic modified objects between the lines, and then accurately express the implicit information when translating. As is shown in TT1, words like technique, stitch, design etc. have been added to highlight the exquisite craftsmanship of Shu embroidery. It is exactly the result of repairing the target eco-environment to balance linguistic ecology. By Addition, the logic of TT becomes clearer and the content of TT can be presented accurately to readers.

\section{B. Balance of cultural ecology between ST and TT}

With regard to the balance of cultural ecology, it mainly concerns with the accurate interpretation of cultural elements and effective transfer of cultural information in the ST. Because of the large number of ICH in China, categories of ICH items are very complex and diverse. Much attention has to be paid to culture-bound terms referring to the elements closely associated with Chinese culture. Given the meaning vacuum resulting from the cultural default, the translator need to rack their brains to convey to TL readers the cultural information that lies behind those terms.

ST2: 评弹, 是评话和弹词的合称。据吴县志记载: “明 清两朝盛行弹词、评话, 二者决然不同, 而总名皆日说 书, 发源于吴中。” (Píngtán, shì pínghuà hé táncí de hé chēng. Jù wú xiànzhì jìzăi: “Míng qīng liăng cháo shèngxíng táncí, pínghuà, èr zhě juérán bùtóng, ér zǒng míng jiē yuē shuōshū, fāyuán yú wú zhōng..)

TT2: Pingtan is the general term for pinghua (storytelling) and tanci (ballad singing). According to the Records of the Wuxian County, "tanci and pinghua, though both popular in the Ming and Qing Dynasties, are not to be confused. They may generally be called storytelling and can find their origin in the central part of the Wu area." (Shanghai Municipal Administration of Culture, Radio, Film \& Television, 2011, p.92) [8]

ST2 is excerpted from the introduction on Pingtan, an art form popular in the Jiangnan area.评弹, 评话 and 弹词 are all terms of Chinese traditional folk art. Such expressions with professional and ethnic feature become the major obstacles of the translation from Chinese to English. As is shown in TT2, 评弹, the title of a ICH item, is directly translated into Pingtan by Transliteration - using Chinese phonetic alphabet to explain the term, while Transliteration plus annotation is adopted to translate other two terms-评话 and 弹词 because it is not enough to convey the cultural message only by Transliteration. Thus TT2 illustrates in brackets the meaning of 评话 and 弹词 after pinghua and tanci in order to further explain the nonexistent information in the TT eco-environment. The application of the method - Transliteration plus annotation is feasible for the translator especially when dealing with culture-bound terms first appeared in the text. It helps to maintain the balance of cultural ecology between ST and TT by making up for the lacking elements in the target ecoenvironment. It is an effective way not only to retain cultural heterogeneity but also to ensure cultural information transfer.

\section{Balance of communicative ecology between ST and TT}

The balance of communicative ecology focuses on the effective transmission of communicative intention. English translation of ICH in China for international publicity aims to promote the understanding and identification of Chinese traditional culture. This is a kind of communicative activity with a strong purpose. In addition to linguistic transformation and cultural transfer, readers' response and expectation should be taken into account in the process of international publicity.

ST3: 顾绣技艺历经明代万历、天启、崇祯三朝 20 年的 磨砺, 成为了有别于日用工艺, 纯观赏性的针刺技艺流 派。(Gù xiù jìy ỳ lìj Ting míngdài wànlì, tiānq İ, chóngzhēn sāncháo 20 nián de mólì, chéngwéile y ǒ u bié yú rì yòng gō ngyì, chún guānsh ă ng xìng de zhēn cì jìyì liúpài.)

TT3: Accumulating 20 years (about 1610s-1630s) of experience, Gu's Embroidery developed into a pure ornamental embroidery art, different from ordinary embroidery techniques. (Shanghai Municipal Administration of Culture, Radio, Film \& Television, 2011, p.135) [8]

Some contents self-evident to SL readers are hard for TL readers to understand, so it would be better to replace these contents with TL readers' unfamiliar information on the premise of retaining the information accuracy of ST. ST3 is about Gu's Embroidery which is named after a family' $\mathrm{s}$ surname. "20 years" proves the long history of this folk art. Here 明代万历, 天启, and 崇祯, the reign titles of three emperors of the Ming Dynasty, have been translated into a period of time-about 1610s-1630s by taking the Gregorian calendar as the reference. By Substitution, the translation becomes more readable to TL readers. It is reasonable when dealing with minor cultural information. After all, the embroidery craftsmanship is the focus of the text above instead of Chinese history. The translation methodSubstitution is adopted to ensure the identical effect of transmission of communicative intention on SL readers and TL readers and maintain the balance of communicative ecology between ST and TT.

To sum up, "Translation as Eco-balance", one of the core concepts of Eco-Translatology, is an applicable strategy for the ICH Chinese-English translation, according to the analysis of the examples above. When translating a text of ICH in China into English, the translator should endeavor to keep the balance of linguistic, cultural and communicative ecology between Chinese text and English text by adopting corresponding translation methods to reconstruct the target eco-environment. 


\section{CONCLUSION}

ICH in China embodies the wisdom of the Chinese nation and profound historical and cultural background of China. Cultural exchange helps to win mutual understanding and respect between civilization, so improving English translation of China's ICH is significant for overseas promotion of Chinese culture. Eco-Translatology provides a new idea for the further study of ICH translation from Chinese to English. In the theoretical framework of Eco-Translatology, the concept of the textual eco-balance is applied as the strategy of translating $\mathrm{ICH}$ in China. Thus the process of translating China' ICH can be taken as maintaining the balance of linguistic, cultural and communicative ecology between Chinese text and English text with the application of translation methods to ensure the accurate and effective transfer of Chinese culture.

\section{ACKNOWLEDGMENT}

This paper is supported by the Educational and Scientific Research Project for the Young and Middle-aged Teachers of Fujian Province in 2017 (Grant No. JAS170406).

\section{REFERENCES}

[1] Text of Convention for the Safeguarding of the Intangible Cultural Heritage. (n.d.). UNESCO. Retrieved May 15, 2018, from https://ich.unesco.org/en/convention

[2] Lu Zhiguo. Translations of Introductive Texts of Intangible Cultural Heritage. Foreign Language \& Literature, vol. 33, 2017, pp.117-121.

[3] Tian Xia. C-E Translation of ICH of Miao Nationality from the Adaptation Theory. Journal of Huaihua University, vol. 31, 2012, pp. 91-94

[4] Chen Fangrong. On Cultural Diversity and the Chinese-English Translation of China's Intangible Cultural Heritage. Journal of Zhejiang Normal University (Social Sciences), vol. 38, 2013, pp. 64-69.

[5] $\mathrm{Hu}$ Gengshen. Eco-Translatology: Construction \& Interpretation. Beijing: The Commercial Press, 2013.

[6] Giuseppe Palumbo. Key Terms in Translation Studies. Beijing: Foreign Language Teaching and Research Press, 2016.

[7] Tang Chaoju et al, eds. Chinese Culture Treasury: Multilingual Introduction to the Catalogue of National Intangible Cultural Heritages in Bashu Region. Chongqing: Chongqing University Press, 2016.

[8] Shanghai Municipal Administration of Culture, Radio, Film \& Television. Illustrated Encyclopedia of Shanghai Intangible Cultural Heritage. Shanghai: Shanghai Culture Publishing House, 2011. 